\title{
Distribution and abundance of zooplankton and Mysis relicta in Flathead Lake
}

STATE DOCUMENTS COLLETTOON

by

Dr. Craig Spencer
AUG 231991

MONTANA STATE LIBRARY IIII. 5 . ETh $\triangle A N E$. HELENA, MONTANA 59320

\section{Flathead Lake Biological Station \\ University of Montana \\ Polson, MT}

Open file report \#122-91

31 May, 1991
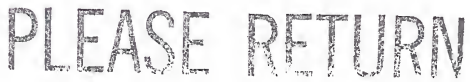

Report to the Montana Department of Fish, Wildlife, and Parks as part of the 1988-1989 Interagency Agreement between the Montana Department of Fish, Wildlife, and Parks and the Flathead Lake Biological Station, University of Montana. 


\section{Table of Contents}

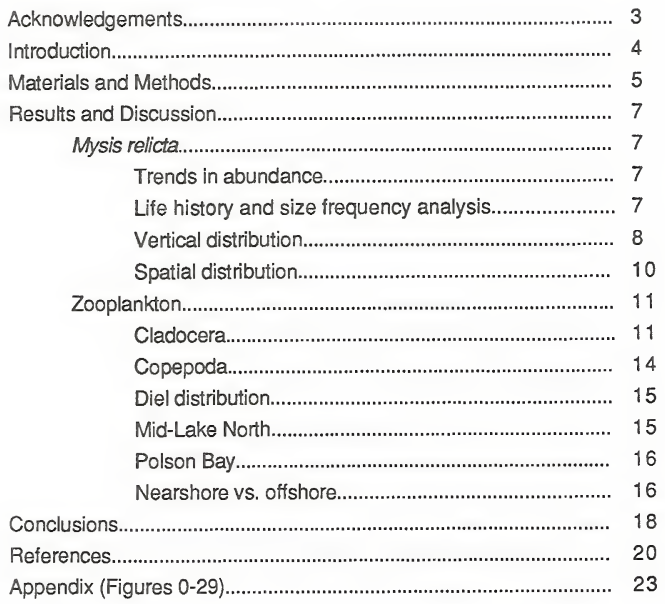




\section{Acknowledgements}

I would like to thank David Potter for use of zooplankton data from his Ph.D. dissertation. Thanks go to Will Beattie, Laney Hanzel, and Scott Rumsey of the MDFWP for cooperation in conducting the field work, and along with John Fraley, for help in developing this cooperative project. Field and lab assistance also was provided by personnel from the Flathead Lake Biological Station including Juan Bosco Imbert, Jim Craft, Ric Hauer, Robin Steinkraus, Joel Tohtz, Mark Potter, and Don Stewart. This work was supported by a grant from the Montana Department of Fish Wildlife and Parks to the University of Montana, Flathead Lake Biological Station. 


\section{Introduction}

During 1960s and early 1970s, Mysis relicta were introduced into more that 100 lakes throughout the northwestern U.S. and British Columbia with the primary intention of providing a supplemental prey organism for salmonids, especially kokanee salmon (Oncorhynchus nerka) (Lasenby et al. 1986, Martinez and Bergerson 1989). Several lakes in the Flathead Lake catchment, northwest Montana, were stocked with M. relicta including Whitefish, Ashley and Swan Lakes. M. relicta are voracious predators on zooplankton, and previous studies have reported significant changes in zooplankton communities following other Mysis introductions (see reviews by Lasenby et al. 1986, Northcote in press). Kokanee salmon also rely on zooplankton as their principle food resource (Cooper and Goldman 1980, Leathe and Graham 1982, Rieman and Falter 1981, Vinyard et al. 1982). Previous introductions of M. relicta have been followed, in some cases, by declines in kokanee abundance. Heightened competition between kokanee salmon and $M$. relicta for declining zooplankton food resources has been implicated as a primary cause for reductions in kokanee abundance (Lasenby et al 1986, Spencer et al. 1991, Northcote in press). In some cases, other factors, including reduction in spawning habitat, have been implicated in kokanee declines (Fraley et al 1986,1989 , Northcote in press).

M. relicta first appeared in Flathead Lake in 1981, presumably the result of downstream movement from previously stocked lakes (Leathe 1984). At that time, kokanee salmon represented the primary sport fish in the Flathead Lake. During the 1970 s there were declines in kokanee spawner abundance in portions of the watershed affected by hydropower operations (Fraley et al 1986, 1989). Nevertheless, a sustained kokanee population and fishery existed in Flathead Lake through the mid-1980s, with adult kokanee populations of several hundred thousand fish, and natural kokanee recruitment of 9 million or more fry per year, coming largely from McDonald Creek in Glacier National Park (Beattie et al. 1988, Clancey and Fraley 1986). Then, within a few years after the appearance of M. relicta, the kokanee showed signs of decline, and by 1987 the fishery collapsed completely (Beattie et al. 1988). There has been considerable debate over the cause of the kokanee collapse in Flathead Lake, and at this time there is general agreement that several factors were involved. These include the introduction of M. relicta., predation by lake trout which expanded following the Mysis introduction, hydropower operations, and angler harvest. 
The present cooperative study between the Montana Department of Fish, Wildlife, and Parks and the Flathead Lake Biological Station was developed to provide information on one of these factors, namely the introduction of $M$. relicta and subsequent changes in the zooplankton community in Flathead Lake. The study also includes information on the distribution and abundance of $M$. relicta in Flathead Lake.

\section{Materials and methods}

\section{Mysis relicta sampling}

The vertical distribution of $M$. relicta was documented through monthly sampling from May through November 1988, at the Mid-Lake Deep site, located in the deepest part of Flathead Lake (Figure 0). Vertical hauls were made with a $1 \mathrm{~m}$ diameter closing net (mesh size 500um) at towing speeds of $0.4 \mathrm{~m} / \mathrm{sec}$ over the following depth intervals: 50 $40 \mathrm{~m}, 40-30 \mathrm{~m}, 30-20 \mathrm{~m}, 20-10 \mathrm{~m}, 10-5 \mathrm{~m}$, and $5 \mathrm{~m}$-surface. Collections were made both during the day (between 1100-1500 hrs) and on moonless nights (with sample collections commencing at least 1 hour after dark). Similar collections were made on four occasions during 1987, however the net was not rigged as a closing net. Therefore, a series of vertical hauls were made from various depths, up to the surface. Densities of $M$. relicta over mid-depth increments were estimated by difference. Monthly Mysis sampling was also conducted in Polson Bay from May through November, 1988. Ten minute horizontal tows were made at night using the same $1 \mathrm{~m}$ diameter net, at towing speeds of $0.4-0.6 \mathrm{~m} / \mathrm{sec}$.

An annual lake-wide census of $M$. relicta was made in late August/early September in 1987 and 1988. A total of 40 sites were selected using a stratified random sampling design in which the lake was divided into three depth strata $(<75 \mathrm{~m}, 40-75 \mathrm{~m}$, $<40 \mathrm{~m}$ ). Single bottom to surface hauls were made at each site with a $1 \mathrm{~m}$ diameter, 500 um mesh net. MDFWP personnel sampled sites at the northern portion of the lake and FLBS personnel sampled the southern portion. Data from all 40 sites were combined to estimate the lakewide density of $M$. relicta.

All M. relicta samples were enumerated, separated by sex, and measured. Juveniles (typically less than $15 \mathrm{~mm}$ in length) were not separated by sex. Up to 50 individuals of each sex were measured in each sample, from the tip of the rostrum to the fork of the telson, using a dissecting microscope at $6 \mathrm{X}$. 


\section{Zooplankton sampling}

Monthly sampling of the vertical distribution of zooplankton was carried out at the same location, time, and depth intervals as the Mysis sampling described previously. We used a $30 \mathrm{~cm}$ diameter, $64 \mathrm{um}$ mesh closing net. In addition, $50 \mathrm{~m}$ to surface hauls were made from January through April 1988. For comparison to pre-Mysis conditions, I used vertical distribution data collected by David Potter (1978) using identical techniques, from May-December 1972 and January-April 1973. For graphical purposes, I placed Potter's data on a single time line, running from January through December, so that the time line would be comparable to 1988 , when samples were collected over the calender year.

Additional zooplankton sampling locations are shown in Figure 0. Monthly zooplankton samples were collected in Polson Bay from May through September, 1988. Duplicate samples were collected over the entire water column. Each sample consisted of a composite of 3 vertical hauls made from the bottom to the surface.

Monthly, duplicate zooplankton hauls also were made at the Mid-Lake North site, from May through November, 1988. Hauls were made from $50 \mathrm{~m}$ to the surface except during periods of thermal stratification, when separate hauls were made from $50 \mathrm{~m}$ to the thermocline, and from the thermocline to the surface.

MDFWP personnel collected zooplankton samples at Lakeside, Somers Bay and Big Arm Bay on a monthly basis from May through September, 1988. Duplicate hauls were made from $\sim 30 \mathrm{~m}$ to the surface except during periods of thermal stratification, when separate hauls were made from $\sim 30 \mathrm{~m}$ to the thermocline, and from the thermocline to the surface.

Macrozooplankton were identified to species and duplicate $1 \mathrm{ml}$ subsamples were enumerated using a Sedgwick Rafter counting cell. Daphnia were measured from the base of the tail spine to the top of the head, using a Whipple grid. 


\section{Results and Discussion}

\section{Mysis relicta}

\section{Trends in abundance}

The population dynamics of Mysis relicta in Flathead Lake represent a classic case of a newly invading species. Following their initial appearance in 1981 , densities of $M$. relicta increased exponentially reaching a maximum density of $129 / \mathrm{m}^{2}$ in 1986 (Figure 1). The maximum density reached by $M$. relicta was well below the level of $1000-2000 / \mathrm{m}^{2}$ predicted by Bukantis (1986), based on densities attained in other large deep oligotrophic lakes in the west, such as Lake Tahoe and Lake Pend Oreille. After peaking in 1986, the density of $M$. relicta declined for three successive years reaching a low of $28 / \mathrm{m}^{2}$ in 1989. This decline in abundance is likely a density dependent response caused by over-exploitation of zooplankton prey (to be discussed in detail later in this report), together with increased fish predation on $M$. relicta.

The plankton community in Flathead Lake is beginning to show signs of stabilizing following the appearance of $M$. relicta in 1981. Following three years of decline, the density of $M$. relicta increased slightly in 1990. Several zooplankton species (described later) which disappeared from lake monitoring samples beginning in 1985, have reappeared in the lake.

\section{Life history and Size Frequency analysis of Mrsis relicta}

Previous work on Flathead Lake from 1984-1986 led R. Bukantis (personal communication) to speculate that the Flathead Lake $M$. relicta population was composed of a single cohort of juveniles, released each spring. These juveniles matured over the summer and produced young the following spring. After releasing their young in the spring, adults persisted for several months, before dying in mid-summer. Size frequency data from 1987 supports the single cohort hypothesis (Figure 2). The size frequency distribution of the juvenile cohort appeared to be normally distributed through July; however, by September the distribution was bimodal. The two observed peaks likely resulted from divergence in size of immature males and females, since the mean size of 
adult females is larger than that of the males as reported by Reynolds and DeGraeve (1972).

In 1988, it appears that two cohorts of juvenile M. relicta were released (Figure 3). A large cohort was released in the spring, followed by a much smaller cohort in July. Each of these cohorts showed evidence of a bimodal distribution by August and September, again presumably due to the increased growth and size of females compared to males.

Analysis of the adult data in Figure 3 shows evidence for a bimodal distribution of females from May through November, 1988. Returning to the 1987 data (Figure 2), there is some evidence for two adult cohorts, particularly on 2 July and 24 July. The extended right shoulder visible for the adult females may represent an older cohort. However, the density of this cohort was quite low.

Given the present data, it is not clear if the bimodal adult distribution, which was distinct in 1988, is due to a subpopulation of adult $M$. relicta which persisted in the lake for an additional year, or if there are simply two subpopulations; an early maturing group and a later maturing group.

\section{Vertical distribution of $M$. relicta}

M. relicta typically inhabit the offshore waters of deep lakes and are noted for their nocturnal habits and pronounced diel vertical migrations (Beeton 1960). During the daylight hours, they typically are found in deep waters, on or near the bottom. At night, they migrate up into the water column (Figure 4). Previous studies have shown that $M$. relicta are quite sensitive to even low levels of light, to the extent that they remain depressed vertically in the water column during full moon nights, compared to cloudy or moonless nights (Beeton, 1960). Nevertheless, during the mid-day sample collections in May 1988, we collected a few juvenile $M$. relicta well off the bottom at depths from $5-20 \mathrm{~m}$ (Figure 4).

In addition to their sensitivity to light, $M$. relicta exhibit marked thermal preferences during their diel migrations. Previous studies indicate that $M$. relicta avoid waters with temperatures above $15^{\circ} \mathrm{C}$ (Beeton 1960). Seasonal vertical distribution patterns from 1988 indicate similar thermal preferences for M. relicta in Flathead Lake (Figure 5). 
During Spring and Fall nights, when lakewide water temperatures were below $14{ }^{\circ} \mathrm{C}, M$. relicta occupied the entire water column, and were most abundant in the top 5 to 10 meters (Figure 5). However, during periods of thermal stratification, few M. relicta were found in the warm epilimnetic waters. During August and September, when the lake was well stratified and epilimnetic temperatures were from $17-20^{\circ} \mathrm{C}$, the thermocline appeared to act as a thermal barrier to most $M$. relicta. At this time of year, the highest densities of $M$. relicta were found just below the thermocline, and very few $M$. relicta were found in the epilimnion. Juvenile $M$. relicta appeared less sensitive to the thermal barrier, especially during July when summer stratification was beginning to set up. Although the greatest density of $M$. relicta in July was from $10-20 \mathrm{~m}$ where water temperatures remained below $15^{\circ} \mathrm{C}$, substantial numbers of juvenile $M$. relicta were found above $10 \mathrm{~m}$, where near surface temperatures exceeded $18^{\circ} \mathrm{C}$ (Figure 5).

Similar vertical distribution patterns were observed in the limited data collections of 1987 (Figure 6). However, enhanced water circulation caused by a mid-July storm produced a decline in surface water temperatures which interrupted the typical seasonal migration pattern of $M$. relicta. By 2 July, a strong thermocline had developed, and epilimnetic water temperatures were from $17-19^{\circ} \mathrm{C}$. Most $M$. relicta remained below the thermocline at this time. However, in mid-July a prolonged storm accompanied by 4 days of strong winds caused a drop in epilimnetic temperatures to approximately $16^{\circ} \mathrm{C}$ on July 24. With this decline in temperature, substantial numbers of juvenile $M$. relicta moved up through the thermocline, all the way to the surface. In September, the epilimnion was $17^{\circ} \mathrm{C}$, and again, the majority of $M$. relicta remained just below the thermocline.

Although there could be other factors which also affect the vertical distribution of M. relicta, the prevailing evidence from this study together with previous research indicates that temperature is a key determinant in the vertical distribution of $M$. relicta. The thermal preferences of $M$. relicta are relatively narrow. From the data presented in this study, it appears that a water temperature change of $1-2^{\circ} \mathrm{C}$ may alter their diel migration patterns. Therefore, the distribution $M$. relicta could be affected by of unusually $\mathrm{cool}$ summers, or disturbance of natural water temperature regimes by upstream discharge of large volumes of cold hypolimnetic water from Hungry Horse dam during the summer and fall. The latter concern should be considered as part of ongoing discussions and plans concerning the operation of Hungry Horse Dam. 


\section{Spatial distribution of M. relicta}

Densities of $M$. relicta generally increased with increasing water depth, as evidenced by data collected in August, 1987 from 40 stations distributed around Flathead Lake (Figure 7). Few M. relicta were collected at sites with water depths $<20 \mathrm{~m}$. Based on this information, we eliminated the depth zone $<20 \mathrm{~m}$ from subsequent lakewide Mysis census estimates and concentrated our efforts in deeper waters.

The majority of $M$. relicta collected in the shallower sites were juveniles (Figure 8). However, with increasing depth, adults tended to make up a greater percentage of the population (Figure 8 ). Not only did the percentage of adults increase with depth, but the average size of adults (both males and females) also increased with increasing depth (Figure 9). From these data, it appears that as M. relicta grow and age, they move into deeper waters. Another possible explanation is that the observed spatial distribution is the result of size selective predation by fish. $M$. relicta located in shallower waters are likely more vulnerable to predation due to greater visibility. Selective predation by fish on larger $M$. relicta could result in reduced average size and age of nearshore $M$. relicta populations. Without corroborating evidence this latter explanation is speculative.

Although the relationship between depth and body size was highly significant for males and female $M$. relicta, there is one data point that deviates widely from the estimate regression lines (Figure 9). The outlier is from a deep-water site, nearshore, just off the mouth of Yellow Bay. The mean size of $M$. relicta at this deep site was smaller than the other deep sites, and appeared to be more typical of shallower sites (Figure 9). This suggests that distance from shore also may be important in the observed size distribution of $M$. relicta (Figure 9). However, this is speculative due to the lack of additional deep, nearshore samples.

\section{Polson Bay - M. relicta}

We conducted a number of nighttime horizontal tows with the Mysis net in Polson Bay during 1988. Only a few $M$. relicta were collected in these tows, and these were exclusively juvenile, collected primarily during the Spring; a few individuals were collected in the Fall. No $M$. relicta were collected in tows made from mid-June through September. Unfortunately the density of $M$. relicta collected in these tows was so low that accurate density estimates were not possible. 
During the summer period, when Flathead Lake is thermally stratified, Polson Bay is largely made up of near-surface waters of Flathead Lake, flowing into Polson Bay through the Narrows (Figure 0). Since few M. relicta are found in surface waters of the lake during the summer (Figure 5), it is not surprising that few M. relicta appeared in our Polson Bay collections during the summer. Of course during the Spring and Fall when surface waters of Flathead Lake drop below $15^{\circ} \mathrm{C}$, nocturnal migration of $M$. relicta from the deep waters just off the Narrows would likely result in the transport of some individuals into Polson Bay, especially during the spring when $M$. relicta are most abundant in the lake.

\section{ZOOPLANKTON (Mid-Lake Deep)}

The results presented here focus on comparison of data collected in 1988 after M. relicta was well established in Flathead Lake with data collected in 1972-73, prior to the appearance of M. relicta. Although there was considerable zooplankton data collected in the intervening years, these data are beyond the scope of this report. Furthermore, data collected in these other years do not contain comparable vertical distribution data as in 1988 and 197273. Rather, these other years contain data from single depth tows, or at most dual tows which are split at the thermocline.

\section{Cladocera}

The zooplankton community changed dramatically in Flathead Lake following the appearance of the voracious planktivore, M. relicta (Bukantis 1986, Beattie et al. 1988, Spencer et al. 1991). Cladocerans are preferred prey for M. relicta (Grossnickle 1982, Nero and Sprules 1986, Cooper and Goldman 1980), and previous Mysis introductions have been linked to disappearance of various Cladoceran species in other lakes including Lake Tahoe and Lake Pend Oreille (Richards et al. 1975, Rieman and Falter 1981). The three dominant Cladoceran species in Flathead Lake all declined in abundance following the appearance of $M$. relicta. However, there were marked differences in the pattern of decline exhibited by the three species. The differential responses may be explained by differences in vertical distribution patterns together with life history traits among the three species. 
In 1972, prior to the appearance of M. relicta, Daphnia longiremis were present in the water column throughout the year (Figure 10). Maximum densities reached levels of approximately $1 / L$ during spring and early summer. $D$. longiremis virtually disappeared from plankton samples from Flathead Lake, beginning in late 1985 and 1986 (Bukantis 1986). No D. longiremis were collected at the Mid Lake Deep sampling site in 1988 (Figure 10).

The vertical distribution of $D$. longiremis makes it especially vulnerable to predation by $M$. relicta. As shown in Figure 11, D. longiremis appears adapted to colder waters as it is concentrated below the thermocline during summer stratification. In the spring and fall, it is concentrated closer to the surface. The year-round vertical distribution pattern illustrated in Figure 11, shows remarkable overlap with the night-time distribution of the plankton predator, M. relicta (Figure 5). Thus the dramatic decline in abundance of $D$. longiremis in 1985, concurrent with greatly increased densities of $M$. relicta, is likely the result of predation by $M$. relicta.

Another disadvantage for $D$. longiremis with respect to vulnerability to predation from $M$. relicta, is that this Cladoceran does not appear to produce ephyppia (resting eggs) in Flathead Lake. This is not uncommon for limnetic Cladocerans in large lakes (Pennak 1978). D. longiremis overwinters in the adult stage, and overwintering individuals remain suspended in the water column throughout the winter (Figure 11). Thus $D$. longiremis is exposed to predation by $M$. relicta throughout the year.

The seasonal population dynamics of Daphnia thorata also have changed since the introduction of $M$. relicta (Figure 12). Although mid-summer densities of $D$. thorata before and after the $M$. relicta introduction are comparable, the total period of dominance by $D$. thorata has been truncated during both spring and fall. Prior to the appearance of $M$. relicta, $D$. thorata were present in substantial quantities $(>1 / L)$ from mid-May through late November (Figure 12). In 1988, D. thorata were only present at those densities from mid-July through early October.

The life history and vertical distribution characteristics of $D$. thorata make it much better adapted to co-existance with the potential predator, $M$. relicta, than $D$. longiremis. $D$. thorata has charactenistics typical of warm water adapted species. Historically, $D$. thorata first appeared in the water column in early spring and then rapidly increased in abundance reaching peak densities by early June (Figure 12). Densities declined slightly during mid-summer and then increased to a second peak in October. These twin 
peaks correspond to spring and fall turnover, and are likely the result of increased food availability resulting from stimulation of primary production in Flathead Lake during these periods (Stanford et al. 1983).

D. thorata reside in the upper $20 \mathrm{~m}$ of the water column from May through November (Figure 13). During summer stratification, they are almost exclusively restricted to the epilimnion. Since the appearance of $M$. relicta, $D$. thorata populations now only develop when the lake in thermally stratified. It is during this time that a thermal refuge for $D$. thorata exists in the epilimnion, which is relatively free of $M$. relicta. During Spring and Fall, M. relicta occupy the entire water column thus there is no refuge for $D$. thorata, and populations are decimated. Unlike $D$. Iongiremis, produce ephyppia in the Fall which likely provides $D$. thorata with an effective means of escaping predation by $M$. relicta over the winter months, when no thermal refuge exists. For most of the year, $D$. thorata populations are made up exclusively of females, which reproduce via parthenogenesis. However, during the fall, male D. thorata appear in the population. Sexually produced ephyppia appear in females by late fall. The ephyppia serve as the overwintering stage for $D$. thorata. Adult $D$. thorata are essentially gone from the water column by January. The thick walled ephyppia sink to the bottom or accumulate along the shoreline. They can withstand drying and freezing (Pennak 1978). Ephyppia hatch in early spring and the cycle begins again.

The response of Bosmina longirostris to $M$. relicta appears to be intermediate between the other two Cladocerans. The abundance of $B$. longirostris was reduced throughout the year in 1988 compared to 1972 (Figure 14); however, substantial numbers of this Cladoceran, up to $2 / \mathrm{L}$, still develop in mid-summer. Even so, peak summer densities declined $~ 50 \%$ in 1988 compared to 1972. Densities throughout the remainder of the year declined 10 fold or more.

Prior to the appearance of $M$. relicta, $B$. longirostris tended to be concentrated in the upper portion of the water column throughout the year (Figure 15). However, the distribution of $B$. longirostris was not as restricted to the warm epilimnetic waters as $D$. thorata (Figure 13). For example, the highest densities of $B$. longirostris during the summer of 1972 were often found within the metalimnion. While few $D$. thorata were ever found below $30 \mathrm{~m}, B$. longirostris densities in excess of $1 / \mathrm{L}$ were measured from $30-40 \mathrm{~m}$ during June and July, 1972, and measurable densities were found as deep as $60 \mathrm{~m}$ during August (Figure 15). Given this vertical distribution, a substantial portion of the $B$. 
longirostris population appeared to be exposed to predation by $M$. relicta during the summer.

In 1988, B. longirostris still did not appear to take advantage of the epilimnetic refuge, as a significant portion of the population remained near or below the thermocline. Like D. longiremis, B. longirostris do not appear to produce ephyppia in Flathead Lake, or in Lake Tahoe (Threlkeld 1981). Thus they too overwinter as adults suspended in the water column where they have no apparent refuge from Mysis predation. This undoubtedly contributed to the dramatic decline in $B$. longirostris densities observed in 1988 , from late fall through winter and spring.

\section{Copepods}

Cyclopoid copepods, primarily Diacyclops thomasii, declined markedly following the appearance of $M$. relicta (Figure 16). In fact, next to Daphnia longiremis, Diacyclops thomasii was the macrozooplankton species which showed the greatest decline following the appearance of $M$. relicta. While declines in Cladocera have been reported following other $M$. relicta introductions (Richards et al. 1975), similar declines in copepods have not been reported. Order of magnitude declines in $D$. thomasii abundance were documented in Flathead Lake. In 1972, cyclopoid densities at Mid-lake Deep remained above $9 / \mathrm{L}$ throughout the year and reached levels up to $25 / \mathrm{L}$ (Figure 16). In 1988 following the appearance of $M$. relicta, the highest cyclopoid density recorded all year was only $2.4 / \mathrm{L}$.

The vertical distribution of Diacyclops thomasii shown in Figure 17 suggests a cold-water distribution, similar to D. longiremis (Figure 11). In 1972 Diacyclops thomasii generally remained below the thermocline during summer stratification. Peak summer densities of Diacyclops thomasii were concentrated from the thermocline down to depths of 40 meters or more. Substantial numbers of Diacyclops thomasii were found as deep as $70-80 \mathrm{~m}$.

Given this year-round vertical distribution, Diacyclops thomasii, together with $D$. longiremis, likely represented the most abundant plankton food resource available for $M$. relicta during the summer. Feeding experiments indicate that next to Cladocera, cyclopoid copepods are the next most preferred macrozooplankton prey (Vanderploeg et al. 1982, Grossnickle 1982). The data suggest that following depletion of the preferred 
Cladoceran prey, M. relicta likely have preyed heavily on Diacyclops thomasii in Flathead Lake.

The response of Leptodiaptomus ashlandii to the appearance of $M$. relicta, offers a distinct contrast to Diacyclops thomasii. Densities of $L$. ashlandii were comparable in 1972 and 1988 (Figure 18), and the mean annual density in 1988 was $4.9 / \mathrm{L}$ compared to $3.71 / \mathrm{L}$ in 1972 . L. ashlandii were concentrated in the upper portion of the water column prior to the Mysis introduction (Figure 19). The highest densities occurred in midsummer and were found in the upper portion of the epilimnion. As such, this species may benefit from the development of the epilimnetic refuge from $M$. relicta. Nevertheless, substantial number of $L$. ashlandii were found below the thermocline during the summer of 1988. Feeding studies indicate that calanoid copepods are less vulnerable to Mysis predation than either Cladocera or cyclopoid copepods (Vanderploeg et al.1982, Grossnickle 1982). In fact, these studies report that adult calanoid copepods were the least preferred of all zooplankton prey.

Following the appearance of $M$. relicta $L$. ashlandii apparently has replaced $D$. thomasii as the dominant copepod in Flathead Lake. Likely explanations for the success of $L$. ashlandii are that it is not a preferred prey of Mysis together with its vertical distribution which favors the epilimnion where Mysis predation is greatly reduced.

\section{Diel zooplankton distributions}

Like $M$. relicta, cladocerans and copepods also may exhibit pronounced diel vertical migrations in lakes (Pennak 1978). However, monthly sampling conducted from May through November 1988 suggest that the zooplankton in Flathead Lake do not undergo marked diel migrations. Vertical profiles of $D$. thorata and $B$. longirostris show only small differences in day and night distributions (Figures 20,21). Copepods (not shown) also exhibited minor differences between day and night distributions.

\section{Mid-Lake North}

The 1988 population dynamics of zooplankton at the Mid-lake North (MLN) station were similar to patterns observed at our primary sampling station at Mid-lake Deep (MLD). However, the density of the various zooplankton groups was slightly lower at MLN (Figure 22). 
Zooplankton densities from the epilimnion and hypolimnion at MLN indicate that densities of most of the the zooplankton groups were higher in the epilimnion than the hypolimnion (Figure 23). This was especially true for $D$. thorata, which was found almost exclusively in the epilimnion at MLN (Figure 23), as was the case at MLD (Figure 13). Bosmina, and both major copepods groups, were generally more abundant in the epilimnion than the hypolimnion at MLN; however, substantial numbers of each of these groups were found below the thermocline. This lends additional support for the hypothesis that the vertical distribution of these zooplankton groups makes them more vulnerable than $D$. thorata to predation by $M$. relicta.

\section{Polson Bay}

The zooplankton community in Polson Bay was similar to MLD in 1988 (Figure 24, 25. This is to be expected given the short retention time of Polson Bay waters, which are continually being replaced by waters flowing in through the Narrows. In late June, 1988, the density of $D$. thorata declined dramatically in Polson Bay (Figure 24). This reduction was preceded by a large storm, accompanied by high winds. Strong water circulation during the storm resulted in a $4^{\circ} \mathrm{C}$ drop in temperature in Polson Bay which was observed throughout the $7 \mathrm{~m}$ deep, water column (Figure 24) The most likely explanation for this rapid decline in temperature is that water circulation during the storm resulted in upwelling of cold hypolimnetic waters from the Narrows into Polson Bay. As discussed previously, the hypolimnetic waters of Flathead Lake have very low zooplankton densities (Figures $11,13,15,17,23$ ). This would appear to explain the concurrent decline in abundance of zooplankton in Polson Bay in late June 1988.

\section{Nearshore verses offshore sites}

For purposes of this report, the offshore zone is defined as the central deep pelagic zone of the lake with water depths from 50 to $100 \mathrm{~m}$. Offshore sites in this study include MLD and MLN (Figure 0). Nearshore sites are located less than $1 \mathrm{~km}$ from shore in water depths generally less than $30 \mathrm{~m}$. Historical zooplankton data collected by David Potter (1978) suggest that nearshore zooplankton populations were comparable to offshore populations in 1972 , prior to the appearance of $M$. relicta. For example, $D$. thorata densities were 
comparable at MLD and Lakeside in 1972 (Figure 26). The densities of cyclopoid copepods also were comparable between these two sites in 1972 (Figure 27). In 1988, there was a sharp contrast between zooplankton populations at the nearshore station at Lakeside, compared to the deep offshore station at MLD. Both cyclopoid copepods and $D$. thorata were drastically reduced at Lakeside, compared to MLD in 1988 (Figure 26,27). When the additional sites at MLN, Somers Bay and Big Arm are added, the nearshore decline in zooplankton is also apparent (Figure 28, 29).

While most of the emphasis on Mysis impacts in other lakes have focused on the offshore zone, the limited data presented above indicate that nearshore zooplankton populations have declined even more than offshore populations in Flathead Lake. This is in contrast to Lake Tahoe, where large bays reportedly serve as refuges for Cladocera following the introduction of Mysis (Threlkeld, 1981). Unfortunately, few nearshore/offshore zooplankton comparisons have been made in other Mysis lakes.

Direct predation by Mysis may only be partially responsible for the observed declines in macrozooplankton in Flathead Lake. The remarkable decline in all macrozooplankton in the nearshore zone, where temperature and light generally exclude Mysis (Beeton and Bowers 1982) suggest that changes in the fish community may have contributed to the community-wide zooplankton changes. Unfortunately quantitative data on nearshore fish populations, pre and post-Mysis are lacking. Nevertheless, qualitative visual observations suggest that yellow perch populations have increased greatly since the appearance of $M$. relicta. Large schools of yellow perch are now quite noticeable throughout the summer along the shoreline of Flathead Lake. These large schools were apparently not present prior to the Mysis invasion.

At this time, we suspect that burgeoning populations of yellow perch may be responsible for the dramatic decline in nearshore zooplankton populations observed in the lake. Comparable expansions in yellow perch populations occurred in Lake Michigan following the introduction of coho and chinook salmon and the subsequent decline in alewife abundance. Expansion of yellow perch in Lake Michigan together with the other fisheries changes also appear linked to dramatic changes in nearshore zooplankton populations there (Scavia et al. 1986, Evans 1986). 
Additional studies are needed before drawing definite conclusions about the nearshore fish/zooplankton interactions in Flathead Lake. Ongoing studies at FLBS are focusing on interactions between $M$. relicta, yellow perch, and other fish species in the food web of Flathead Lake.

\section{Conclusions}

This report along with previous studies (Bukantis and Bukantis 1987, Beattie et al. 1988, Spencer et al. 1991, Beattie and Clancey 1991) documents significant changes in the zooplankton community of Flathead Lake following the appearance of the voracious zooplankton predator, $M$. relicta. Daphnia longiremis virtually disappeared from the lake, while cyclopoid copepods have declined in abundance by an order of magnitude. Both of these organisms are poorly adapted to co-existance with $M$. relicta. They do not have a dormant, winter resting stage and, like $M$. relicta, these organisms occupy the coldwater regions of the lake. Thus both organisms are vulnerable to predation by $M$. relicta throughout the year.

Daphnia thorata and the calanoid copepods are better adapted to co-existance with $M$. relicta. Both of these organisms are concentrated in the warm waters of the epilimnion during summer thermal stratification of Flathead Lake. M. relicta generally remain below the thermocline, thus the epilimnion serves as an effective refuge from Mysis predation for warm water zooplankters like Daphnia thorata and the calanoid copepods. This epilimnetic refuge lasts only for 3-4 months during the summer, and for the remainder of the year, $M$. relicta are found throughout the entire water column. Consequently, few Cladocerans are now found in the water column from October through June.

Daphnia thorata produce ephyppia in autumn, and these lie dormant in the lake sediments over the winter. These resting eggs appear to provide an effective refuge from predation for $D$. thorata from fall through spring when $M$. relicta forage throughout the water column.

Nearshore zooplankton populations have declined even more than offshore populations following the appearance of $M$. relicta in Flathead Lake. Densities of all 
macrozooplankton in this region in 1988 were severely depressed throughout the year compared to 1972 . Since few $M$. relicta occupy the nearshore zone, direct predation by $M$. relicta does not appear to be responsible for the nearshore zooplankton decline. We suspect that changes in the fish community of Flathead Lake following the Mysis invasion, have resulted in increased zooplankton predation in the nearshore environment by planktivorous fish such as yellow perch. However, further studies are needed before definitive conclusions can be drawn on food web interactions in the nearshore environment. 


\section{REFERENCES}

Beattie, W., P. Clancey, and R. Zubik. 1988. Effect of the operation of Kerr and Hungry Horse dams on the reproduction success of kokanee in the Flathead system. Project No. 81S-5. (Report to the Bonneville Power Admin., Portland, OR., Montana Dept. of Fish. Wildlife, and Parks, Kalispell, MT), 89p.

Beattie, W.P. and P. Clancey. In press. Effects of the establishment of opossum shrimp (Mysis relicta) on the zooplankton community, and coincident decline in the survival of kokanee (Oncorhynchus nerka) in Flathead Lake, Montana. Am. Fish. Soc. special publ.

Beeton, A.M. 1960. The vertical migration of Mysis relicta in Lakes Huron and Michigan.J. Fish. Res. Bd. Can., 17: 517-539.

Bowles, E.C., B.E. Rieman, G.R. Mauser, and D.H. Bennett. In press. Effects of mysid introductions on fishery resources in Northern Idaho. Am. Fish. Soc. special publ. Bukantis, R. 1986. Mysis: friend or foe. Yellow Bay Journal. 4: 1,12-15.

Bukantis, R.T. and J.G. Bukantis. 1987. Mandibles. Montana Outdoors 18: 15-17, 26. Clancey, P. and J. Fraley. 1986. Effects of the operation of Kerr and Hungry Horse Dams on the kokanee fishery in the Flathead River system. Project No. 81-S5. (Report to the Bonneville Power Admin., Portland, OR., Montana Dept. of Fish. Wildlife, and Parks, Kalispell, MT), 45p.

Cooper, S.D. and C.R. Goldman. 1980. Opossum shrimp (Mysis relicta) predation on zooplankton. Can. J. Fish. Aquat. Sci. 37: 909-919.

Evans, M.S. 1986. Recent major declines in zooplankton populations in the nearshore region of Lake Michigan: Probable causes and implications. Can. J. Fish. Aquat. Sci. 43:154-159.

Fraley, J.J., S.L. McMullin, and P.J. Graham.1986. Effects of hydroelectric operations on the kokanee populations in the Flathead River System, Montana. N. Am. J. Fish. Man. 6: 560-568.

Fraley, J. and J. Decker-Hess. 1987. Effects of stream and lake regulation on reproductive success of kokanee in the Flathead River System, Montana, U.S.A. Regulated Rivers: Research and Management 1:257-265.

Fraley, J. B., Marotz, J. Decker-Hess, W. Beattie, and R. Zubik. 1989. Mitigation, compensation, and future protection for fish populations affected by hydropower development in the Upper Columbia system, Montana, U.S.A. Regulated Rivers: Research and Management 3: 3-18. 
Grossnickle, N.E. 1982. Feeding habits of Mysis relicta - an overview. Hydrobiologia 93: 101-107.

Hanzel, D. A. 1969. Flathead Lake, investigation of its fish populations and its chemical and physical characteristics. Project F-33-R-3, Job No. I. Job Final Report.

Montana Department of Fish and Game, Kalispell, MT.

Hanzel, D. A. 1976. History of northern pike in the Flathead River. Montana

Department of Fish and Game, Kalispell, MT.

Lasenby, D.C., T.G. Northcote, and M. Furst. 1986. Theory practice, and effects of Mysis relicta introductions to North American and Scandinavian lakes.Can.J. Fish.

Aquat. Sci. 43: 1277-1284.

Leathe, S.A. 1984. Opossum shrimp: a controversial new resident of Flathead Lake. Western Wildlands 9: 10-14.

Leathe, S.A. and P.J. Graham. 1982. Flathead Lake Fish Food Habits Study, (Final Report to the EPA, Denver, CO., Montana Dept. of Fish. Wildlife, and Parks, Kalispell, MT. 137p.

Martinez, P. J. and E.P. Bergersen. 1989. Proposed biological management of Mysis relicta in Colorado lakes and reservoirs. N. Amer. J. of Fish. Man. 9:1-11.

Nero, R.W. and W.G. Sprules. 1986. Predation by three glacial opportunists on natural zooplankton communities. Can. J. Zool. 64:57-64.

Northcote, T.G. 1972. Some effects of mysid introduction and nutrient enrichment on an oligotrophic lake and its salmonids. Verh. Internat. Verein. Limnol. 18: 1096-1106. Northcote, T.G. 1973. Some impacts of man on Kootenay Lake and its salmonids. Great lakes Fish. Comm. Tech. Rep. No. 25: 46p.

Northcote, T.G. In press. Successes, problems, and control of introduced mysid populations in lakes and reservoirs. Am. Fish. Soc. Special Symp. Series.

Pennak, R.W. 1978. Fresh-water invertebrates of the United States. John Wiley Publ. 803p.

Potter, D.S. 1978. The Zooplankton of Flathead Lake: an Historical Review with Suggestions for Continuing Lake Resource Management. Ph.D. Diss. U. Montana, Missoula. 393 p.

Reynolds, J.B. and G.M. DeGraeve. 1972. Seasonal population characteristics of the opossum shrimp Mysis relicta, in Southeastern Lake Michigan, 1970-1971. 1972. Great Lakes Res. 131?:117-131.

Richards, R.C., C.R. Goldman, T.C. Frantz, and R. Wickwire. 1975. Where have all the Daphnia gone? The decline of a major cladoceran in Lake Tahoe, CaliforniaNevada. Verh. Internat. Verein. Limnol. 19: 835-842. 
Rieman, B.E. and B. Bowler. 1980. Kokanee trophic ecology and limnology in Pend Oreille Lake. Fisheries Bulletin No. 1, idaho Dept, of Fish and Game, Boise.

Rieman, B.E. and C. M. Falter. 1981. Effects of the establishment of Mysis relicta on the macrozooplankton of a large lake. Trans. Am. Fish. Soc. 110: 613-620.

Scavia, D., G.L. Fahnenstiel, M.S. Evans, D. Jude, and J.T. Lehman. 1986. Influence of salmonine predation and weather on long-term water quality trends in Lake Michigan. Can. J. Fish, Aquat. Sci. 43:435-443.

Spencer, C.N., B.R. McClelland, and J.A. Stanford. 1991. Shrimp stocking, salmon collapse and eagle displacement: Cascading interactions in the food web of a large aquatic ecosystem. Bioscience 41:14-21.

Stanford, J.A., T.J. Stuart, and B.K. Ellis. 1983. Limnology of Flathead Lake. Final Rept. to the U.S.E.P.A. $101 p$.

Stanford, J.A. and B.K. Ellis. 1988. Pages 11-32 in Our Clean Water: Flathead's Resource of the Future Proceedings of a conference, April 25-26, 1988, Flathead Basin Commission, Helena, MT.

Threlkeld, S.T. 1981. The recolonization of Lake Tahoe by Bosmina longirostris: evaluating the importance of reduced Mysis relicta populations. Limnol. Oceanogr. 26:433-444.

Vanderploeg, H.A., J.A. Bowers, O. Chapelski, and H.K. Soo. 1982. Measuring in situ predation by Mysis relicta and observations on underdispersed microdistributions of zooplankton. Hydrobiologia 93:109-119.

Vinyard, G.L., R.W. Drenner and D.A. Hanzel. 1982. Feeding success of hatchery reared kokanee salmon when presented with zooplankton prey. Prog. Fish. Cult., 44: 37-39.

Wells, L., and A. McLain. 1972. Lake Michigan: effects of exploitation, introductions, and eutrophication of the salmonid community. J. Fish. Res. Bd. Can. 29: 889-898. 


\section{APPENDIX}

Figures 0-29 


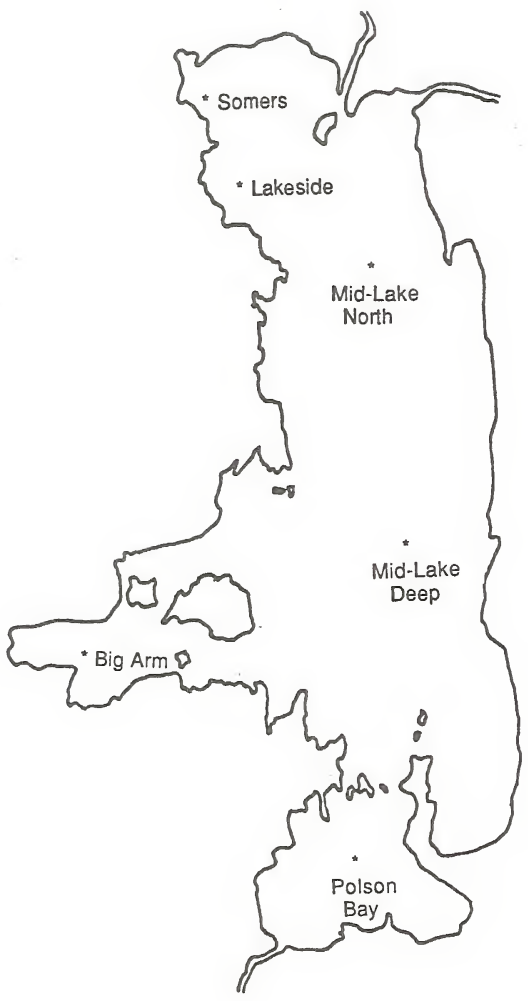

Figure 0. Map of Flathead Lake showing primary sampling stations. 


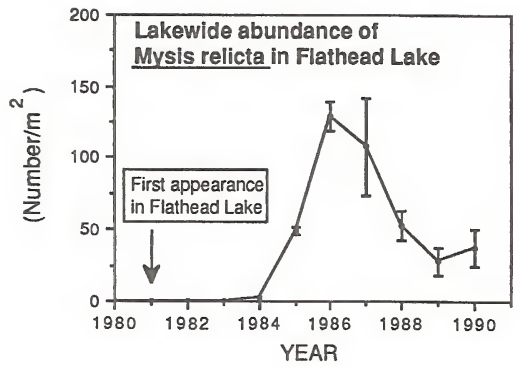

Figure 1. Annual autumn census of $M$. relicta abundance in Flathead Lake. Error bars represent $95 \%$ confidence intervals. 

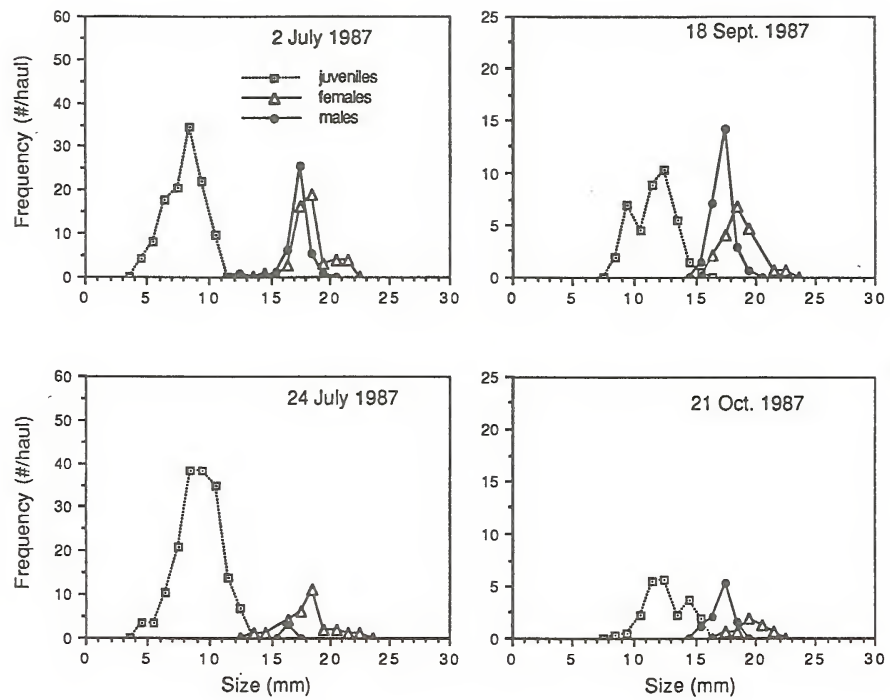

Figure 2. Size frequency distribution of $M$. relicta collected in 1987 at the Mid-Lake Deep station in Flathead Lake. 

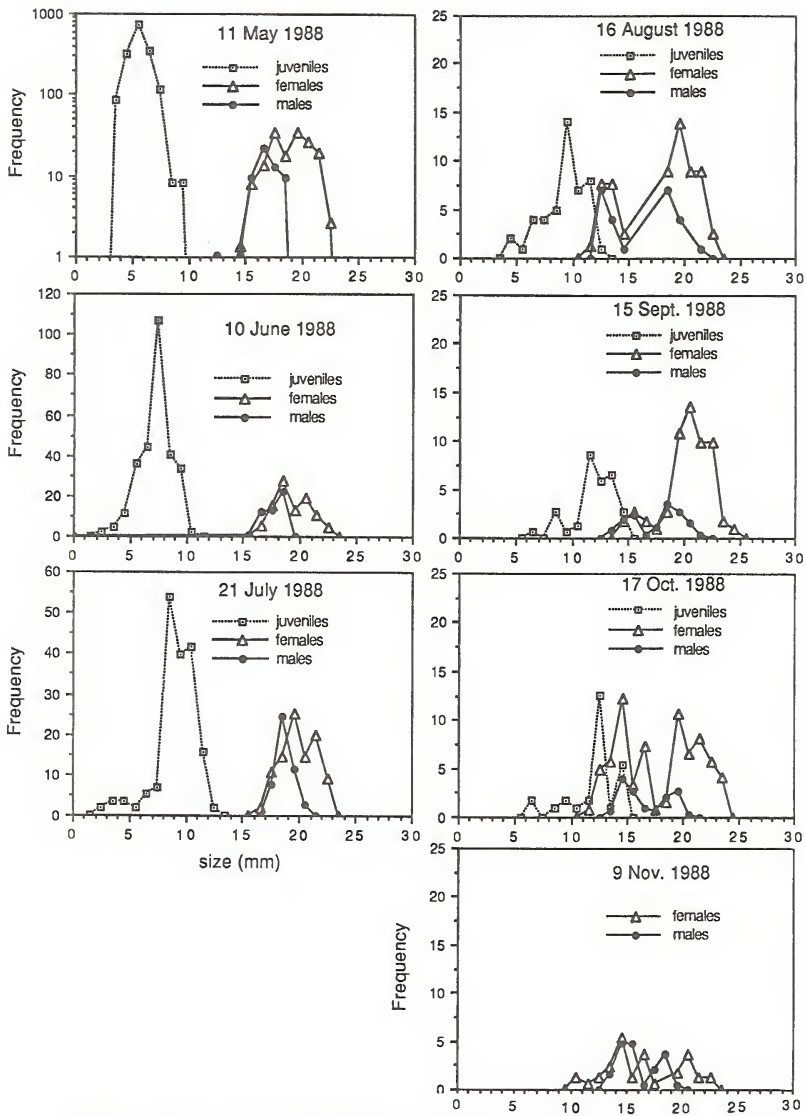

Figure 3. Size frequency distribution of $M$. relicta collected in 1988 at the Mid-Lake Deep station in Flathead Lake. 

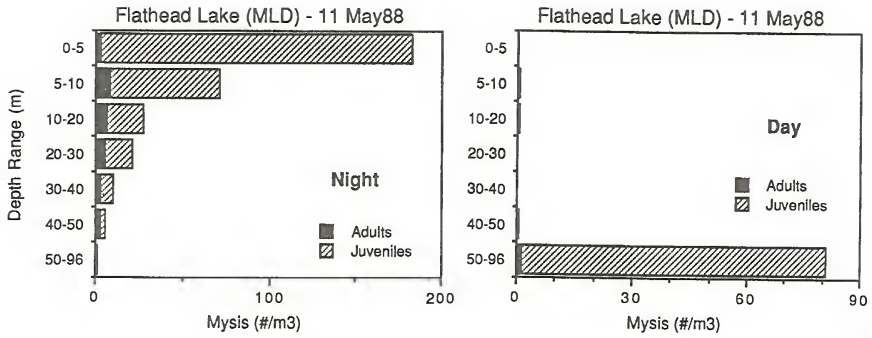

Figure 4. Vertical distribution of M. relicta on May 11, 1988 at mid-day and mid-night at the Mid-Lake Deep station in Flathead Lake. The organisms observed between $20 \mathrm{~m}$ and $5 \mathrm{~m}$ during the daytime samples are juvenile M. relicta. 

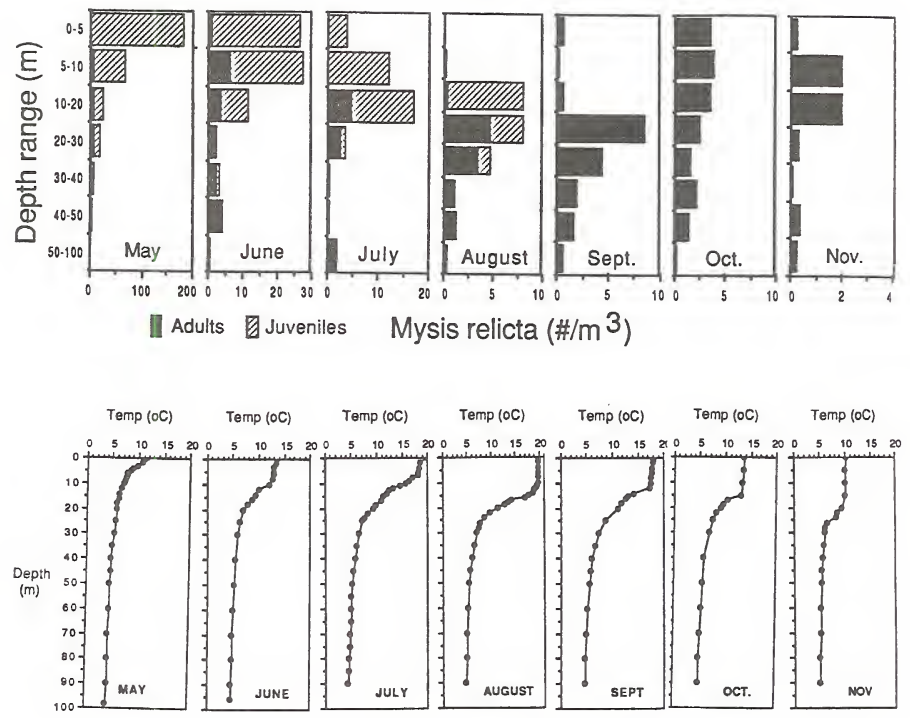

Figure 5. Temperature profiles and vertical distribution of $M$. relicta from May through November, 1988 on moonless nights at the Mid-Lake Deep station in Flathead Lake. 

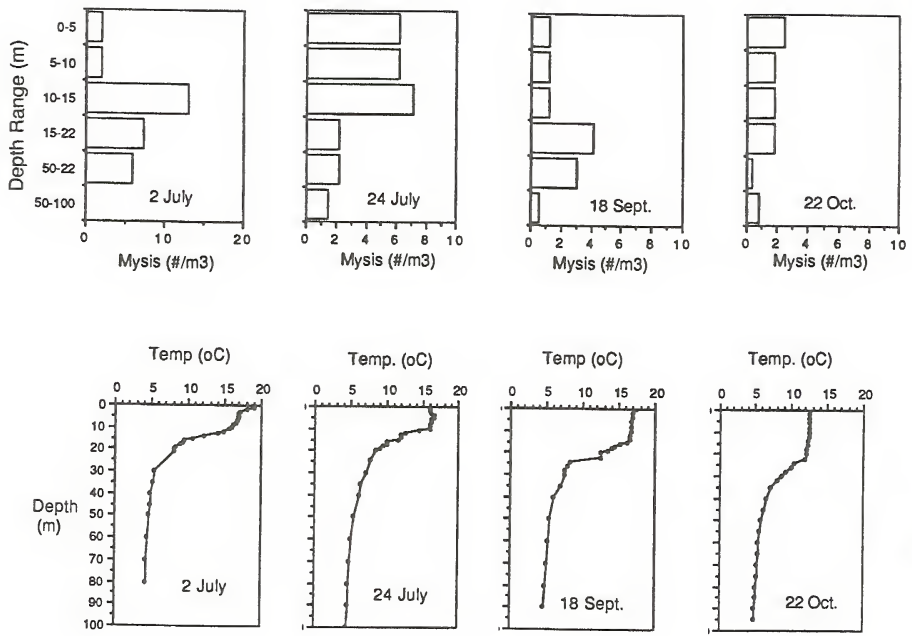

Figure 6. Temperature profiles and vertical distribution of $M$. relicta from July through October, 1987 on moonless nights at the Mid-Lake Deep station in Flathead Lake. 


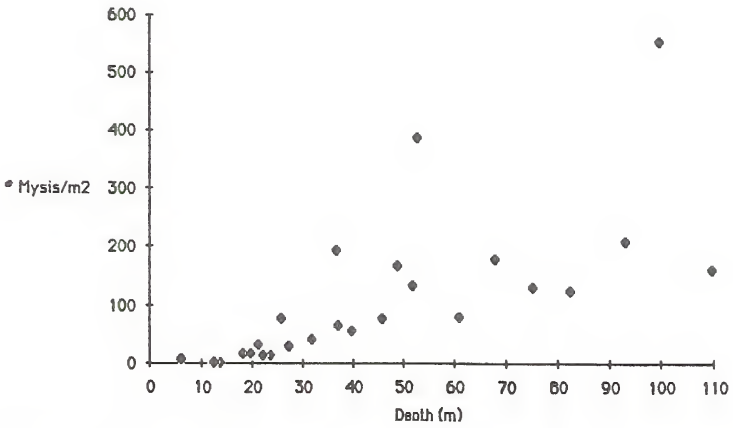

Figure 7. Relationship between sampling site depth and Mysis abundance at 40 randomly selected sites in Flathead Lake during the August 31, 1987 Mysis census. 

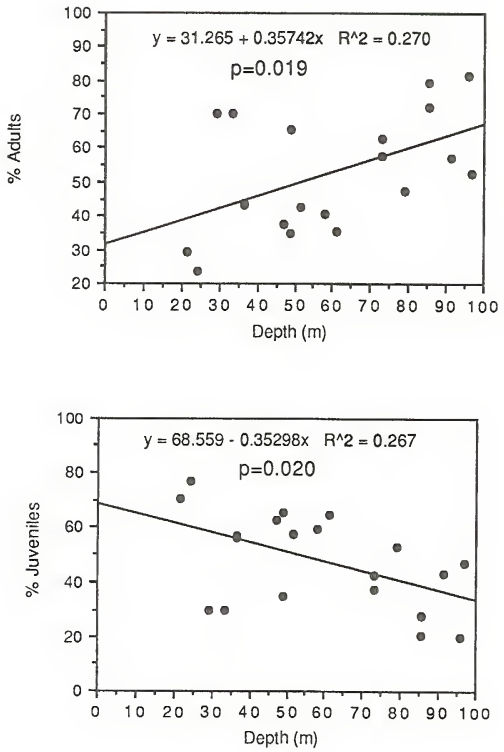

Figure 8. Relationship between sampling depth and the $\%$ of adult and juvenile M. relicta at FLBS sampling sites during the 1988 autumn Mysis census. 

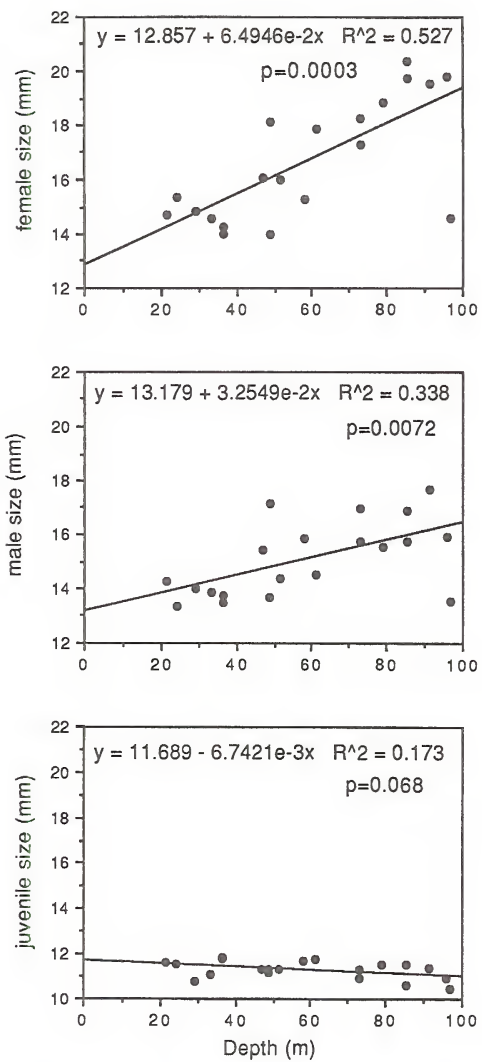

Figure 9. Relationship between sampling depth and the size of female, male, and juvenile M. relicta at FLBS sampling sites during the 1988 autumn Mysis census. 


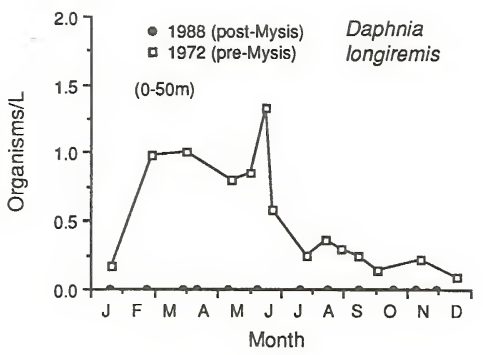

Figure 10. Seasonal abundance of Daphnia longiremis in 1972 (open symbols) and 1988 (closed symbols) at the Mid-Lake Deep station in Flathead Lake. Densities were calculated by summing up incremental $10 \mathrm{~m}$ hauls from $50 \mathrm{~m}$ to the surface. No D. longiremis were collected in 1988. 


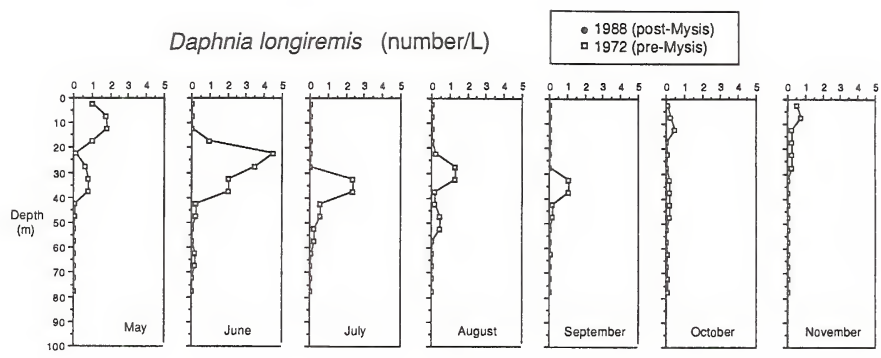

Figure 11. Vertical distribution of Daphnia longiremis (\#/L) from May through November, in 1972 (open symbols), and 1988 (closed symbols) at the Mid-Lake Deep station in Flathead Lake. No D. longiremis were collected in 1988. 


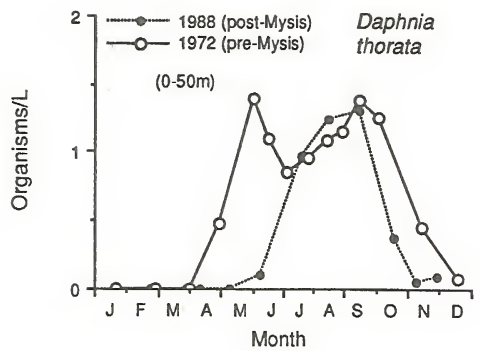

Figure 12. Seasonal abundance of Daphnia thorata in 1972 (open symbols) and 1988 (closed symbols) at the Mid-Lake Deep station in Flathead Lake. Densities were calculated by summing up incremental $10 \mathrm{~m}$ hauls from $50 \mathrm{~m}$ to the surface. 

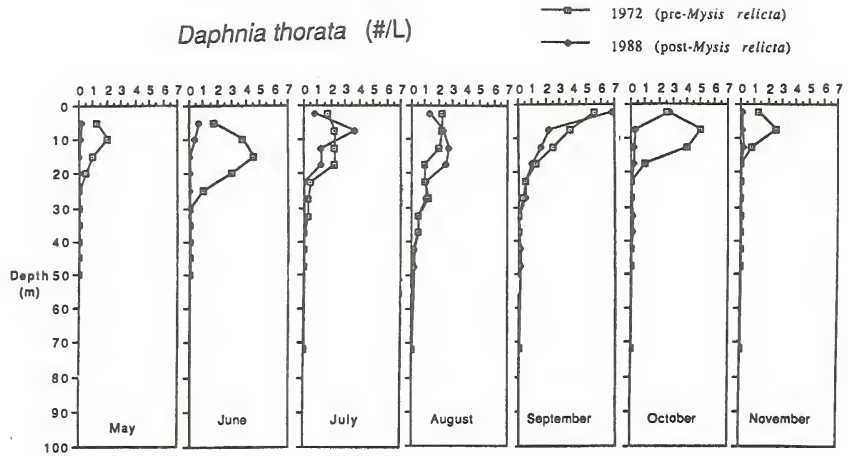

Figure 13. Vertical distribution of Daphnia thorata (\#/L) from May through November, in 1972 (open symbols), and 1988 (closed symbols) at the Mid-Lake Deep station in Flathead Lake. 


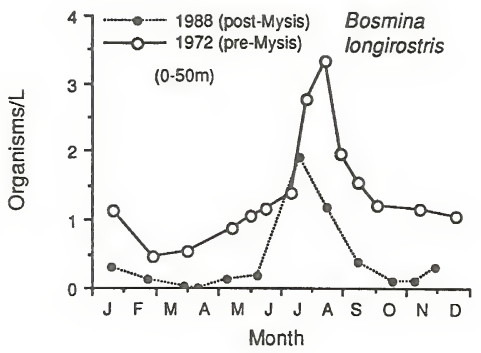

Figure 14. Seasonal abundance of Bosmina longirostrisin 1972 (open symbols) and 1988 (closed symbols) at the Mid-Lake Deep station in Flathead Lake. Densities were calculated by summing up incremental $10 \mathrm{~m}$ hauls from $50 \mathrm{~m}$ to the surface. 


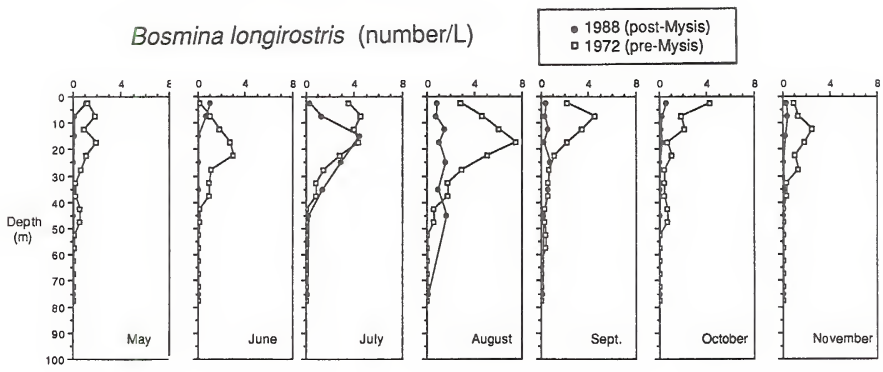

Figure 15. Vertical distribution of Bosmina longirostris (\#/L) from May through November, in 1972 (open symbols), and 1988 (closed symbols) at the Mid-Lake Deep station in Flathead Lake. 


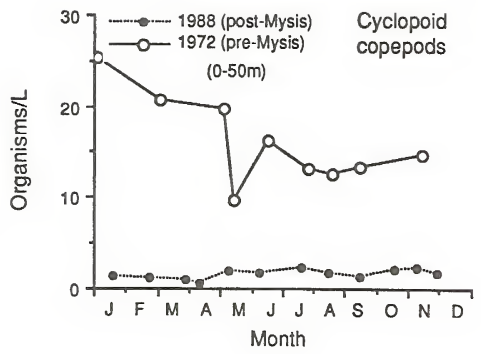

Figure 16. Seasonal abundance of cyclopoid copepods in 1972 (open symbols) and 1988 (closed symbols) at the Mid-Lake Deep station in Flathead Lake. Densities were calculated by summing up incremental $10 \mathrm{~m}$ hauls from $50 \mathrm{~m}$ to the surface. 
Cyclopoid copepods (number/L)

- 1988 (post-Mysis)

- 1972 (pre-Mysis)
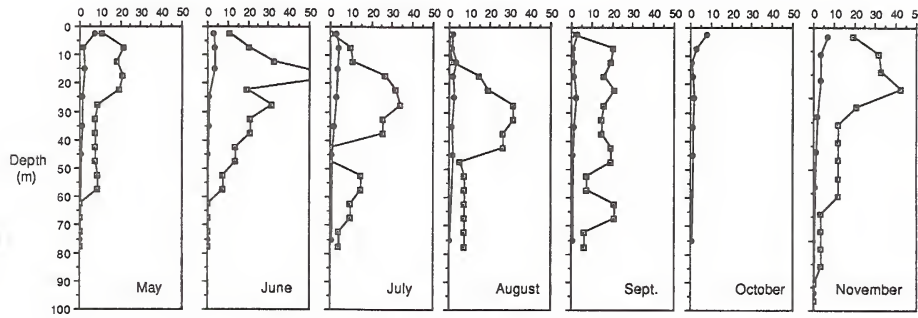

Figure 17. Vertical distribution of cyclopoid copepods (\#/L) from May through November, in 1972 (open symbols), and 1988 (closed symbols) at the Mid-Lake Deep station in Flathead Lake. 


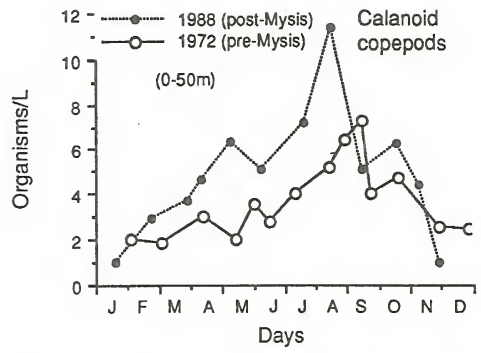

Figure 18. Seasonal abundance of calanoid copepods in 1972 (open symbols) and 1988 (closed symbols) at the Mid-Lake Deep station in Flathead Lake. Densities were calculated by summing up incremental $10 \mathrm{~m}$ hauls from $50 \mathrm{~m}$ to the surface. 
Calanoid copepods (number/L)

- 1988 (post-Mysis)
- 1972 (pre-Mysis)
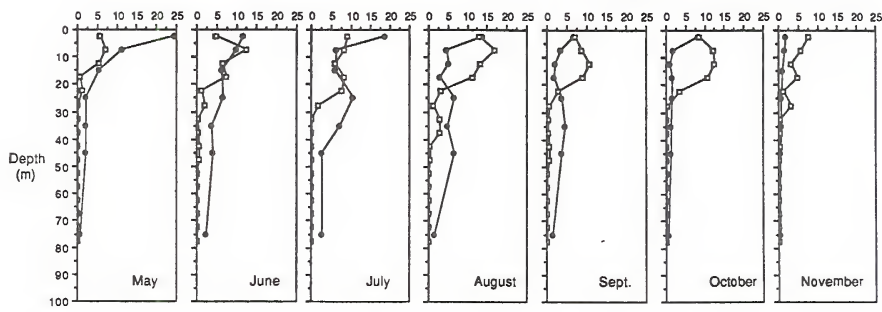

Figure 19. Vertical distribution of calanoid copepods (\#/L) from May through November, in 1972 (open symbols), and 1988 (closed symbols) at the Mid-Lake Deep station in Flathead Lake. 


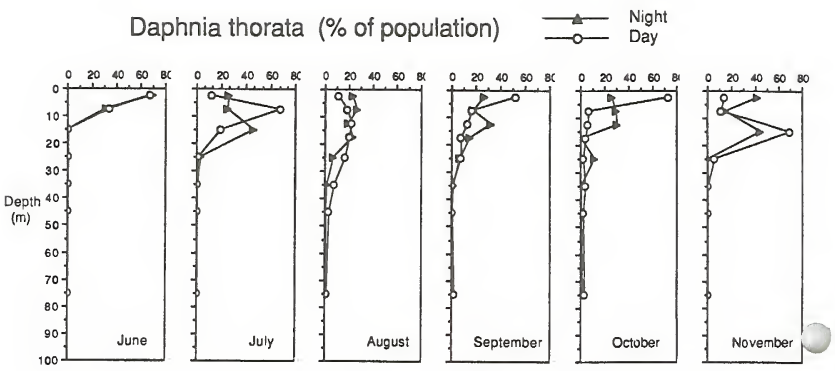

Figure 20. Vertical distribution of Daphnia thorata (\#/L) from May through November, 1988 at mid-dav (open symbols), and mid-night (closed symbols) at the Mid-Lake Deep station in Flathead Lake. Note, no Daphnia thorata were collected in the May 1988 samples. 


\section{Bosmina longirostris (\% of population) $=$ Night}
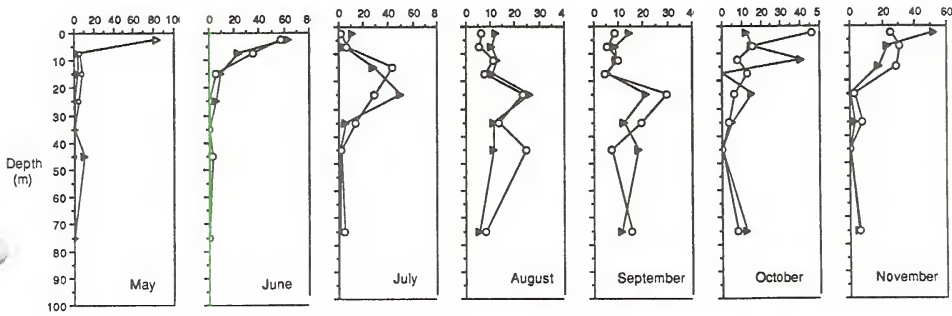

Figure 21. Vertical distribution of Bosmina longirostris (\#/L) from May through November, 1988 at mid-day (open symbols), and mid-night (closed symbols) at the Mid-Lake Deep station in Flathead Lake. 

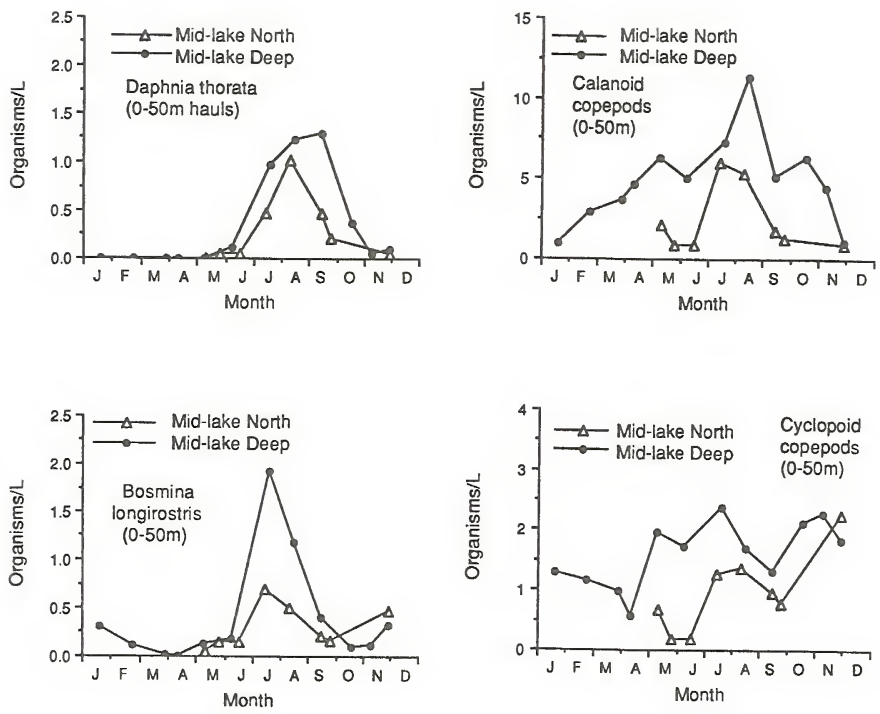

Figure 22. Seasonal abundance of the dominant macrozooplankton at the Mid-Lake North and Mid-Lake Deep stations in Flathead Lake during 1988. Densities at MLD were calculated by summing up incremental $10 \mathrm{~m}$ hauls from $50 \mathrm{~m}$ to the surface. Densities at MLN were calculated from $50 \mathrm{~m}$ to surface hauls from January-June and November, and on the other dates by summing up incremental hauls from $50 \mathrm{~m}$ to the thermocline and from the thermocline to the surface. 

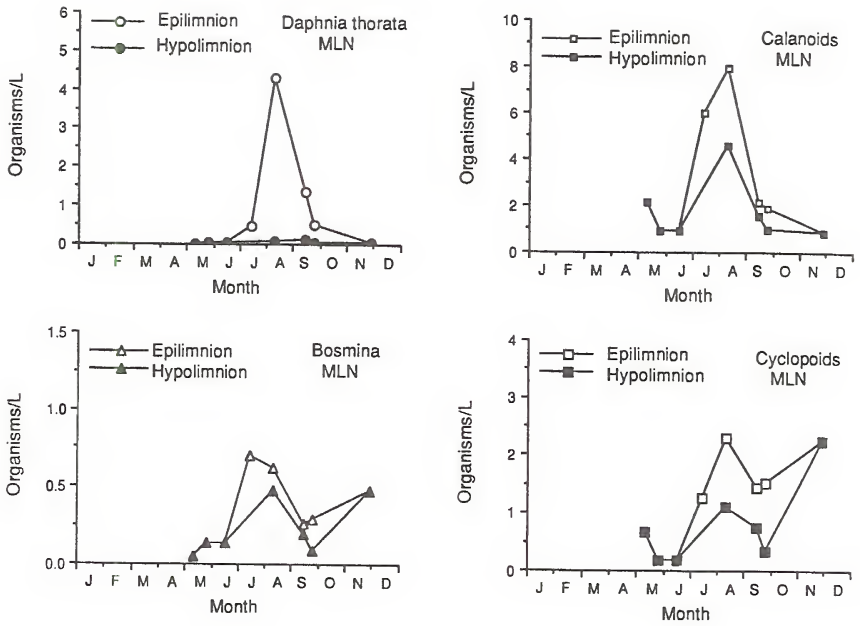

Figure 23. Seasonal abundance of the dominant macrozooplankton in the hypolimnion ( $50 \mathrm{~m}$ to the thermocline) and epilimnion (thermocline to the surface) at the Mid-Lake North station in Flathead Lake during 1988. Densities at MLD were calculated by summing up incremental $10 \mathrm{~m}$ hauls from $50 \mathrm{~m}$ to the surface. Densities at MLN were calculated from $50 \mathrm{~m}$ to surface hauls from January-June and November, and on the other dates by summing up incremental hauls from $50 \mathrm{~m}$ to the thermocline and from the thermocline to the surface. 

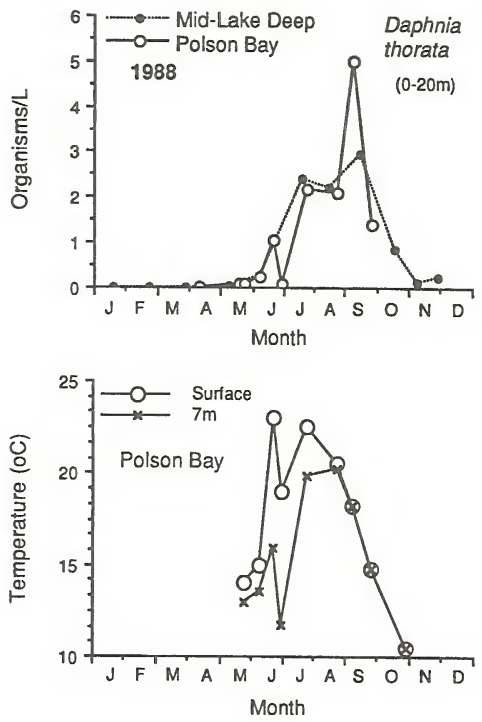

Figure 24. Seasonal abundance of the dominant macrozooplankton at Polson Bay and Mid-Lake Deep stations in Flathead Lake during 1988. Densities at MLD were calculated by summing up incremental $10 \mathrm{~m}$ hauls from $20 \mathrm{~m}$ to the surface. Densities at Polson Bay were calculated from bottom $(\sim 6 \mathrm{~m})$ to surface hauls. 

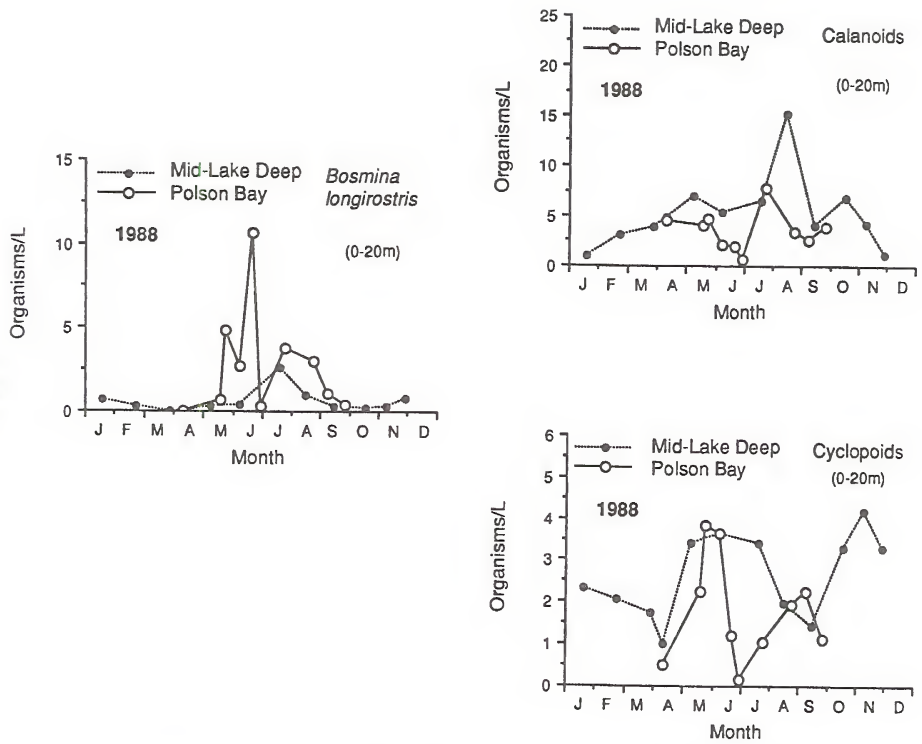

Figure 25. Seasonal abundance of the dominant macrozooplankton at Polson Bay and Mid-Lake Deep stations in Flathead Lake during 1988. Densities at MLD were calculated by summing up incremental $10 \mathrm{~m}$ hauls from $20 \mathrm{~m}$ to the surface. Densities at Polson Bay were calculated from bottom $(\sim 6 \mathrm{~m})$ to surface hauls. 

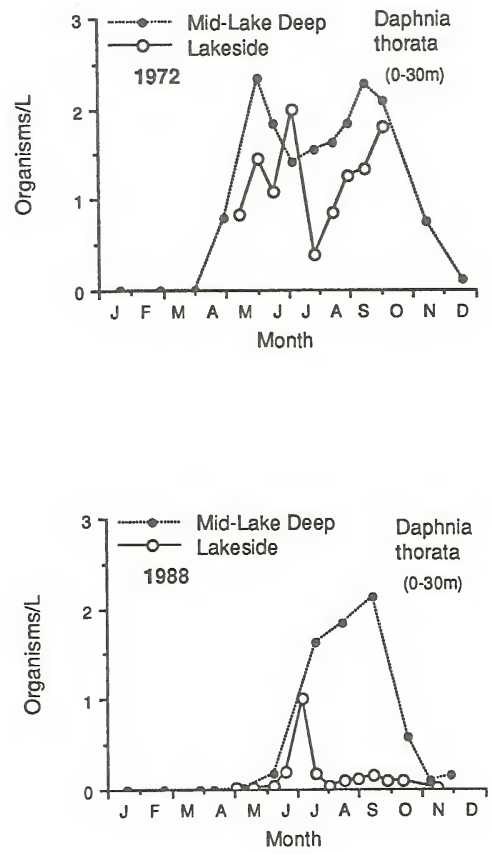

Figure 26. Seasonal abundance of Daphnia thorata at the Lakeside and MidLake Deep stations in Flathead Lake during 1972 (top graph) and 1988 (bottom graph). Zooplankton densities were calculated by summing up incremental $10 \mathrm{~m}$ hauls from $30 \mathrm{~m}$ to the surface. 

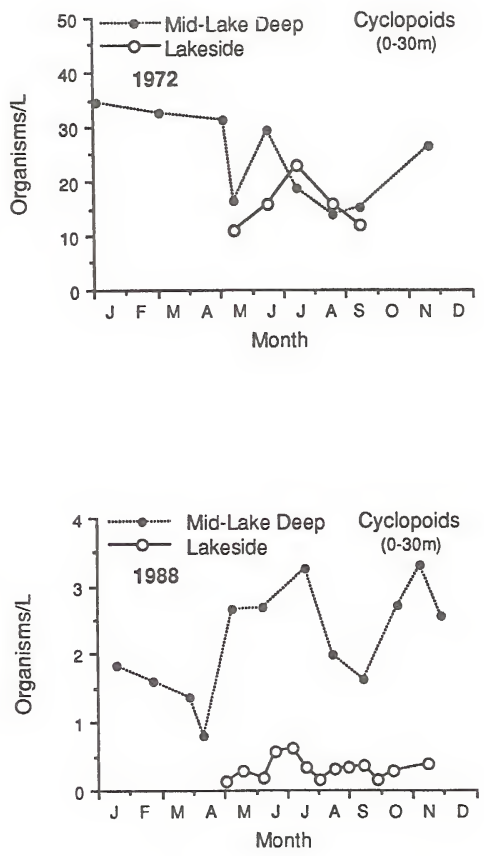

Figure 27. Seasonal abundance of Cyclopoid copepods at the Lakeside and Mid-Lake Deep stations in Flathead Lake during 1972 (top graph) and 1988 (bottom graph). Zooplankton densities were calculated by summing up incremental $10 \mathrm{~m}$ hauls from $30 \mathrm{~m}$ to the surface. 

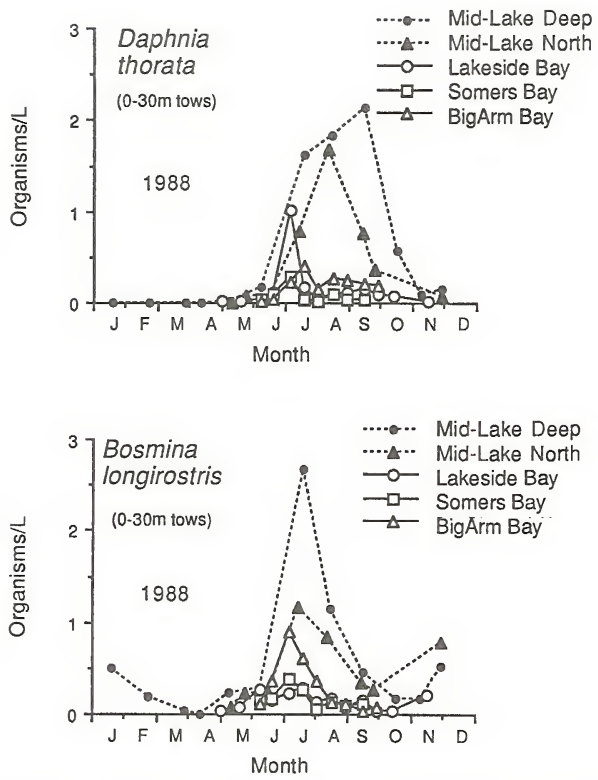

Figure 28. Seasonal abundance of Daphnia thorata and Bosmina longirostris at two offshore deep sites and 3 nearshore bay sites in Flathead Lake during 1988. Zooplankton densities at MLD and Lakeside were calculated by summing up incremental $10 \mathrm{~m}$ hauls from $30 \mathrm{~m}$ to the surface. Zooplankton densities at Somers Bay, and Big Arm Bay were estimated during summer stratification by adding vertical hauls from $25-30 \mathrm{~m}$ to the thermocline and the thermocline to the surface, and for the rest of the year from $25-30 \mathrm{~m}$ to surface hauls. 

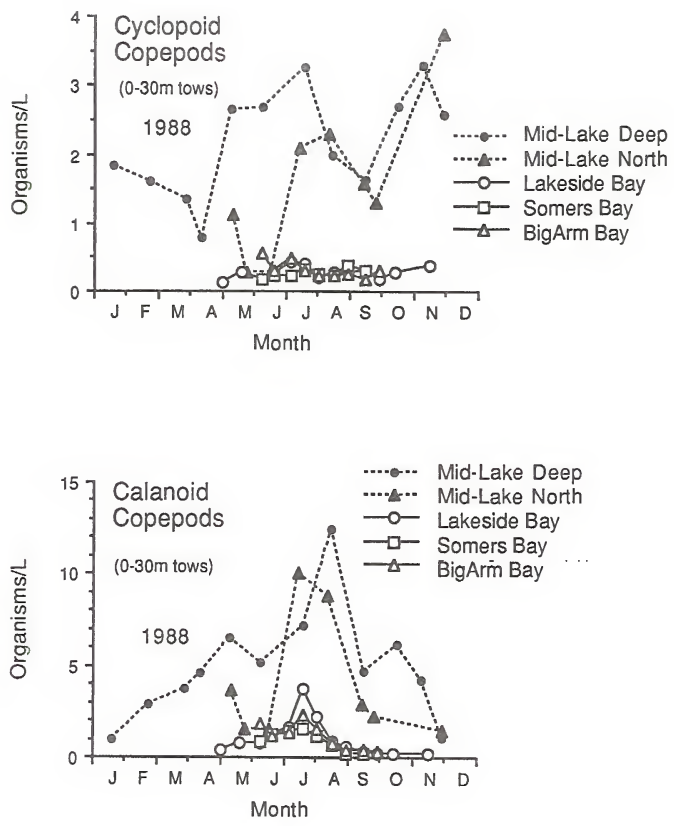

Figure 29. Seasonal abundance of cyclopoid and calanoid copepods at two offshore deep sites and 3 nearshore bay sites in Flathead Lake during 1988. Zooplankton densities at MLD and Lakeside were calculated by summing up incremental $10 \mathrm{~m}$ hauls from $30 \mathrm{~m}$ to the surface. Zooplankton densities at Somers Bay, and Big Arm Bay were estimated during summer stratification by adding vertical hauls from 25$30 \mathrm{~m}$ to the thermocline and the thermocline to the surface, and for the rest of the year from $25-30 \mathrm{~m}$ to surface hauls. 
